Florida International University FIU Digital Commons

2012

\title{
Taking Issue with History: Empathy and the Ethical Imperatives of Creative Interventions
}

Monica A. Vera

Florida International University, mvera008@fiu.edu

DOI: $10.25148 /$ etd.FI12120503

Follow this and additional works at: https://digitalcommons.fiu.edu/etd

\section{Recommended Citation}

Vera, Monica A., "Taking Issue with History: Empathy and the Ethical Imperatives of Creative Interventions" (2012). FIU Electronic Theses and Dissertations. 776.

https://digitalcommons.fiu.edu/etd/776

This work is brought to you for free and open access by the University Graduate School at FIU Digital Commons. It has been accepted for inclusion in FIU Electronic Theses and Dissertations by an authorized administrator of FIU Digital Commons. For more information, please contact dcc@fiu.edu. 


\title{
FLORIDA INTERNATIONAL UNIVERSITY
}

Miami, Florida

\section{TAKING ISSUE WITH HISTORY: EMPATHY AND THE ETHICAL IMPERATIVES OF CREATIVE INTERVENTIONS}

\author{
A thesis submitted in partial fulfillment of \\ the requirements for the degree of \\ MASTER OF ARTS \\ in \\ ENGLISH \\ by
}

Monica A. Vera 
To: Dean Kenneth G. Furton

College of Arts and Sciences

This thesis, written by Monica A. Vera, and entitled Taking Issue with History: Empathy and Ethical Imperatives of Creative Interventions, having been approved in respect to style and intellectual content, is referred to you for judgment.

We have read this thesis and recommend that it be approved.

Ana Lusczcynska

Heather Russell

Steven Blevins, Major Professor

Date of Defense: November 8, 2012

The thesis of Monica A. Vera is approved.

Dean Kenneth G. Furton
College of Arts and Sciences

Dean Lakshmi N. Reddi
University Graduate School

Florida International University, 2012 
ABSTRACT OF THE THESIS

TAKING ISSUE WITH HISTORY: EMPATHY AND THE ETHICAL IMPERATIVES

OF CREATIVE INTERVENTIONS

by

Monica A. Vera

Florida International University, 2012

Miami, Florida

Professor Steven Blevins, Major Professor

The purpose of this thesis was to contribute to a dialogue that considers the relationship between history, literature, and empathy as a literary affect. Specifically, I explored sites of literature's transformative potential as it relates to cultural studies and the ethics of deconstruction. Via a deconstructive, post-colonial reading of Toni Morrison's Beloved and Junot Díaz's The Brief Wondrous Life of Oscar Wao, I considered how subjects in our current socio-political moment can feel history.

Emerging from a post-structurally mediated engagement with history, signification, and feeling, I argued that empathy, as it is contentiously presented in the context of deconstruction, is not necessarily a reductive or essentialist approach towards relating or "being-with" an-other. Instead, I proposed that the act of reading historiographical novels that take constructions of the Atlantic Slave Trade to task might generate an affective empathy, which could in turn engender a more empathetic relationality and way of being-in-the-world. 


\section{DEDICATION}

This project is dedicated to those upon whom my being-in-the-world depends and whose histories have made me. To my parents, Oscar and Virginia Vera: you have cultivated my love of stories, instilled in me the will to persevere, and your emotional (and financial!) support has allowed me to pursue my intellectual curiosity - for that I am eternally grateful. Para mi abuela, Maria del Carmen Gonzalez: tú apoyo, cariño, y cafés con leche me han alimentado el alma, y no hay manera adecuada de expresar mi gratidud, pero tratare - mil gracías. Finally, to my siblings, Oscarito, Danny, and Caro: you are my beings-in-feeling and constant reminders to keep writing towards righting the wrongs we inherit, and to push through the limits of imagination. Thank you. 


\section{ACKNOWLEDGMENTS}

This project would not have been possible without the guidance, tough love, and sincere support from my thesis committee, Steven Blevins, Ana Luszczynska, and Heather Russell. You have all shown me the value of teaching, and given me the tools with which to embark upon the next leg of my journey. There are not enough words to adequately express my gratitude. I admire you and thank you for your friendship.

I would also like to thank my friends and colleagues, Isabel Sanchez, Elaine Pritzker, and Jessica Petit-Frere for being there from the beginning and making the path towards a Master's degree a bit less arduous.

I am also thankful to Anthony Entrialgo and Diane DeZinno for their generosity, humor, and above all, for becoming a home away from home. I am additionally grateful to Diego Polar, Marie Montaner, Francesco Giuffra, Bobby Brennan, Vincent Chu, Brooke Perry, and Krystel Garcia for showing me that family is not only defined by blood, but by the love and memories that bind us.

Furthermore, I am grateful to Dr. James Sutton, Dr. Asher Z. Milbauer, and the entire Department of English at Florida International University, for giving me the opportunity to turn my love of stories into a discipline with which to think about the world around me in more critical ways, and for giving me the tools to work towards a more just and ethical world.

Finally, I would have been unable to obtain this degree, or complete this project, without the support of my family. Collectively, you have made me aware of my own potential, and did not allow me any choice but success. Thank you. 


\section{TABLE OF CONTENTS}

CHAPTER

PAGE

Part I. The Ethics of Interrogation: Affect, Empathy, History........................

Part II. Bearing Witness and Being-With: Deconstructing Empathy....................13

Part III. Empathy, Absence, and Identification in Toni Morrison's Beloved...............20

Part IV. Empathy, Mediation, and Bearing Witness in The Brief Wondrous Life of Oscar

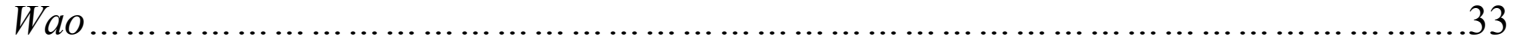

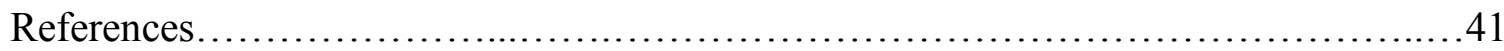


Taking Issue With History: Empathy and the Ethical Imperatives of Creative Interventions

\section{Part 1. The Ethics of Interrogation: Affect, Empathy, History}

"Fictional world-making is only ever as effective as the participatory reader makes it, through active cocreation. The capacity of human beings to engage intellectually and emotionally with imaginary worlds and their denizens places narrative empathy at the intersection of aesthetics, psychology, and philosophy."

-Suzanne Keen, Empathy and the Novel

The purpose of this project is to present a reading of Toni Morrison's Beloved and Junot Díaz's The Brief Wondrous Life of Oscar Wao that frames these texts as exemplary creative interventions with the potential for motivating an affective empathy. ${ }^{1}$ Empathy, then, becomes a way to feel history by way of Nancian singular plurality $\&$ being-with, thus inaugurating subjectivities that might begin to take issue with the problem of history and historiography regarding the trans-Atlantic Slave Trade. Arguably, by approaching history through the lens of affective empathy, the inaugurated subject has the potential to engage in a more ethical way of being-in-the-world. Ideally, this project will help address the anxieties surrounding the construction of a history that accounts for the realities of the Atlantic Slave Trade and its aftermath by considering the intersection of empathy, ethics, and history. "Realities," here, not only refers to the "factual" events that led to the capturing and transporting of enslaved Africans to the New World, but also to one of the problems produced by this violent transition: the issue of engaging and understanding the lived experiences of the black women and men whose identities were "written" by the

\footnotetext{
${ }^{1}$ In Empathy and the Novel, Suzanne Keen "affirms the robustness of narrative empathy, as an affective transaction accomplished through the writing and reading of fiction, but [she] hesitate[s] to tether readers' empathy to certain outcomes of altruistic action" (xv). Keen's analysis is thorough and comprehensive, but ultimately finds little evidence to indicate a causal link between narrative empathy and altruism. I argue, however, that empathy is something different from what Keen understands as empathy, especially in relation to historiographical novels that engage the trauma of the Atlantic Slave Trade.
} 
Colonizers in documents that have often been construed as "official" historical accounts. The fact that our current geo-political and socio-cultural conditions are mediated, not only by the event of enslavement, but also by accounts of enslavement, means we must consider the ways in which it becomes possible to intervene upon histories constructed in ways that perpetuate an epistemology of binary thinking and hierarchical relationality.

In order to begin questioning ways to intervene upon the archives of history, it is useful to consider how Saidiya Hartman's provocative essay, "Venus in Two Acts," negotiates the demand to historicize with the ethical problems she finds in the act of historicizing. In January of 2008, Hartman's Lose Your Mother was released to critical acclaim. As The New York Times notes, “Hartman's main focus in Lose Your Mother is shaking up our abstract, and therefore forgettable, appreciation for a tragedy wrought on countless nameless, faceless Africans" (Schmidt). Achieving her purpose, though, proves difficult for Hartman because of "the huge gaps she encounters in her archival work" (Schmidt). Similarly, in "Venus in Two Acts" (published in June of 2008), Hartman reflects on her own practice of historicizing, and its failure to achieve the recuperative ends she hoped would free Venus from "the banal chronicles" of history (3). Hartman struggles with the notion that Venus's story is an "untimely" one "told by a failed witness" and is compelled to "tell a story" that helps fill the void left by the Western understanding of the enslaved as entirely dejected victims (2). For Hartman then, it is paramount not only to locate sites in the archive where the autonomy of the enslaved was depicted, but also to take on the task of writing enslaved bodies as agents. To do so, however, would be to impose the breath of life on a consciousness and experience that cannot be known. In other words, for Hartman, the act of reanimating Venus's historical 
presence would require her to enact the same violence that was forced upon Venus in the first place, because it would do the work of consolation. Hartman's issue with this kind of personal consolation is that it turns Venus into another kind of instrument or tool with which to soothe the aches of enslavement's trauma. It is the problem of reanimating Venus on the same terms that determined her economic value, which serves as the crux to Hartman's exploration of the potential redemptive power of a creative intervention. She asks, "Is it possible to construct a story from 'the locus of impossible speech' or resurrect lives from the ruins? Can beauty provide an antidote to dishonor, and love a way to 'exhume buried cries' and reanimate the dead?" (3). Although Hartman recognizes the impossibility of engaging with a cohesive and complete understanding of the lives of enslaved Africans, she is not content to leave it at that. Why then does Hartman end her trajectory by not writing Venus? She says,

My account replicates the very order of violence that it writes against by placing yet another demand upon the girl, by requiring that her life be made useful or instructive, by finding in it a lesson for our future or a hope for history (14).

These demands highlight the economic rhetoric that marks Venus's presence in the archive.

Hartman ultimately decides that she cannot recover the story of Venus and ends her piece by underscoring the importance of recognizing that we cannot rescue the many Venuses from the violence that erased their voices from existing constructed histories. Nonetheless, it seems that - at the very least - we can attempt to understand history as we receive it with an awareness of the ways in which it excludes multiple perspectives and 
"establishes who we are in relation to who we have been," as well as question, challenge, and "interrogat[e] the production of our knowledge about the past" (Hartman 14). In fact, it is this manner of questioning that demonstrates the ethics of historicizing in Hartman's piece. Hartman's questioning and its attendant affective qualities help cultivate our own ethics of interrogation. Therefore, it would follow that as long as we self-consciously call attention to our recuperative attempts, to our struggle to understand the violence of slavery, and how that struggle requires creative interventions, we should poke, prod, and problematize the constructed histories that surround the Atlantic Slave Trade and its remnants in our sociocultural psyche. Further, because Hartman is "engendered" by history, this urge is a personal and seemingly ethical endeavor that would, ultimately, generate an imaginative space with the potential to intervene (4).

Hartman's self-reflection is more explicitly rendered in terms of Beloved in Sharon Patricia Holland's chapter entitled "Bakulu Discourse: Bodies Made 'Flesh' in Toni Morrison's Beloved" when she says that "[t]he value of black femaleness...is intrinsically linked to her utilitarian purpose - her service to both the community and the academy. We make the experiences of other people more real to them" (Raising the Dead 42). The problems Holland finds in this construction of black femaleness, is that it reproduces the economic politics of enslavement by making black bodies tools with which to gain access to the million nameless lives of the enslaved. But does this problem mean that we should not attempt to access the narratives and experiences that are omitted from the archive? Or does this problem encourage us to figure out new avenues by which to access those omissions? Holland writes, 
Black female bodies serve as passage between humanity and nonhumanity as well as the articulation of that passage...this border, which is no border at all but a passageway, also encompasses the terrain between the living and the dead, between the ancestral and the living community. (43) I suggest that the most ethical approach we can take to this problem is to engage the kind of telling that novels like Beloved and Brief Wondrous Life can provide in order to maneuver the difficult ethical concerns regarding the act of writing on behalf of the enslaved, and also about the ethical concerns in writing about the enslaved. These ethical concerns, though, should not preclude our attempts to better understand the horror of enslavement, but they do push us to identify the ethical approaches that may facilitate the experience. In this sense, Beloved and The Brief Wondrous Life of Oscar Wao, become the vehicles that can "formulate a new understanding of signs and signifiers and their literal ... mean[ing] felt relationship to black women [and men]" (Holland 44).

While Hartman and Holland's analyses of the discourses about enslavement and the historiography that constructs enslaved bodies based on terms of "value" and "usefulness" are extremely significant, it seems as though they further the silence of enslaved black women, and the recuperative attempts of those who want to reconfigure their presence in historical accounts. In fact, Hartman is paralyzed by these considerations. She writes;

But in the end I was forced to admit that I wanted to console myself and to escape the slave hold with a vision of something other than the bodies of two girls settling on the floor of the Atlantic (9). 
The problem Hartman finds in her urge to recover Venus from the archive is that she is doing so in order to be consoled on an individual, and thus self-serving dimension. As Junot Díaz articulates in an interview with Yale Literary Magazine, "crying is something you do for yourself. Change is what you do for the collective" (30). If we understand Hartman's desire to be consoled as the emotive result of losing something she desperately wants to recover (or something she never had), then consolation remains problematic. However, if we frame her desire to be consoled as something she can work through not only for herself, but for all of us, then her act of historicity holds incredible redemptive potential. Therefore, we will frame Hartman's concerns in the context of the latter formulation, which then forces me to ask: what is wrong with wanting to be consoled? Is it not important to imagine enslaved subjects in the myriad directions they were sent in? Is it not our responsibility to understand that while many enslaved peoples were swallowed up by the Atlantic, there were many who reached the shores of the New World, and who had opportunities for agency and action despite the cruel, inhumane limits that colonization and the institution of enslavement imposed upon them? And because we are all engendered by history, and by the fissures that the Atlantic Slave Trade has left in our sociocultural modalities today, do we not have a right to be consoled? Furthermore, where does this urge to give voice to the absences in history come from? How are we, in our specific sociocultural moment in time, to fairly and ethically account for the erasures, reductions, and dangerous generalizations that mediate our understanding and engagement with enslaved subjects in a Western-sanctioned history? 
The questions I have asked above are motivated by Hartman's ethical interrogation of her relationship to the archive, but are also in dialogue with Hayden White's perspective on the problem of historiography. White more closely attends to the ethics of interrogating the intersection of epistemological constructions, narrative, and history when he notes,

One of the ways that a scholarly field takes stock of itself is by considering its history. Yet it is difficult to get an objective history of a scholarly discipline because if the historian is himself a practitioner of it, he is likely to be a devotee of one or another of its sects and hence biased; and if he is not a practitioner, he is unlikely to have the expertise necessary to distinguish between the significant and insignificant events of the field's development... One must try to get behind or beneath the presuppositions which sustain a given type of inquiry and ask the questions that can be begged in its practice in the interest of determining why this type of inquiry has been designed to solve the problems it characteristically tries to solve" ("The Historical Text as Literary Artifact," pp. 81, Tropics of Discourse).

Like Hartman, White is calling for the kind of questioning that requires us to "get behind or beneath" history, which allows us to imagine how to intervene in ways that do not simply reproduce these discursive and economic relations. Through a mode that works with these subversions, and that ruptures into the historical archive, we are compelled toward sites that attempt to re-negotiate the lived experiences of the enslaved.

Furthermore, White's framing presupposes the aforementioned problems that are inherent 
in academic or scholarly constructions of history, and identifies these sites as ones that need to be dismantled before we can even begin to arrive at the solutions they try to provide.

The issues of history's more material consequences are evident in the way in which history constructs what Edouard Glissant refers to as the "collective consciousness" of Caribbean peoples in "The Quarrel with History" (61). Glissant argues that this collective consciousness is problematic precisely because it cannot exist insofar as it is mediated by the rupture between the lived experiences of those existing in the vestiges of slavery and colonization, and, the experiences of the colonizers who tell the story. According to Glissant,

the French Caribbean is the site of a history characterized by ruptures and that began with a brutal dislocation, the slave trade. Our historical consciousness could not be deposited gradually and continuously like sediment, as it were, as happened with those peoples who have frequently produced a totalitarian philosophy of history, for instance European peoples, but came together in the context of shock, contraction, painful negation, and explosive forces. This dislocation of the continuum, and the inability of the collective consciousness to absorb it all, characterize what I call a nonhistory. The negative effect of this nonhistory is therefore the erasing of the collective memory...our history emerges at the edges of what we can tolerate, this emergence must be related immediately to the complicated web of events in our past. The past, to which we were 
subjected, which has not yet emerged as history for us, is, however, obsessively present. (61-63)

For Glissant, the most effective way to negotiate this problem of history is by challenging the epistemological models that produce our understanding of history and History itself. Glissant calls upon the power of myth to decenter Western "man" (read peoples) from "the center of things," but more importantly, he points out that this decentering has to be acknowledged by Western "man" himself (74). He challenges the prioritization of "realism-objectivity" by proposing that "one might prefer the attempt to completely reconstruct (or to recreate) in depth one part of this reality" (74). Glissant attempts to negotiate the interstices of history and literature that situate a hierarchical understanding of "knowing" in opposition to a lived reality that is informed by an individual's relationship to myth and stories. It is this challenging of established modes of what counts as knowledge, and its potential for decentering Western "man," that seems to have redemptive power for Glissant, and thus, "makes a creative approach necessary" (62). In fact, Glissant notes, "What is repressed in our history persuades us, furthermore, that this is more than an intellectual game" (66). In other words, the urge to recuperate the aspects of history that are lost to us, is more than intellectually motivated, and is instead, driven by a need for consolation that is necessary collective insofar as

We are the roots of a cross-cultural relationship. Submarine roots: that is, floating free, not fixed in one positions in some primordial spot, but extending in all directions in our world through its network of branches. (Glissant, 67) 
The use of the pronoun "we," underscores the importance of this project for all postcolonial subjects, particularly if we consider that regardless of our current geographical location, socio-cultural and political conditions, we are all necessarily subjects of and subject to the demands of history, and are very closely mediated by the event of enslavement. Moreover, as we will later explore, the use of the pronoun "we" becomes the vehicle by which we can access the phenomenological being-with so central to Jeanluc Nancy's project. This recognition leads us to ask: how we can get at a poetics of feeling history?

I would suggest that Wilson Harris's, "History, Fable and Myth in the Caribbean and Guianas" (1999) helps answer the above question and attempts to "clear the kind of historical stasis which has afflicted the Caribbean" by considering "perspectives of renascence which can bring into play a figurative meaning beyond an apparently real world or prison of history" (Selected Essays of Wilson Harris, 152, 156). By way of the limbo dance, a re-articulation of an African myth, Harris exemplifies the physical and historical ruptures that Glissant articulates, and gestures towards the notion of a collective consciousness when he says,

In fact here, I feel, we begin to put our finger on something which is close to the inner universality of Caribbean man. Those waves of migration which have hit the shores of the Americas - North, Central and South century after century have, at various times, possessed the stamp of the spider metamorphosis, in the refugee flying from Europe or in the indentured East Indian and Chinese from Asia (157). 
Here, Harris supports my point that the trans-Atlantic Slave Trade has, in some way or another, determined the current conditions of "post-colonial" subjects in a global sense, based on the "inner universality of Caribbean man." That is not to say that all Caribbean people share the same traits, but rather that Caribbean "man" and peoples of the Americas, and Europe, East India, Asia, etc., all "possess the stamp of the spider metamorphosis" by way of migration patterns that can, to some extent, be linked to the event of enslavement and the consequences of the economy which it produced. As Holland elaborates, "These bodies pass into a new self. To be defined - in both destiny and legal language - by their captors" (47). It is our task, then, to imagine our way beyond the definitions of the captors in order to trouble the dominant historiographical discourse of enslavement.

Furthermore, Harris's idea of a "phantom limb" becomes a useful way to articulate historical elements that are felt in their absence. This phantom limb works to remind us, then, that "the re-assembly of dismembered man or god - possesses archetypical resonances - that embrace Egyptian Osiris, the resurrected Christ, and the many-armed deity of India" (Harris, 158). The fact that Western-sanctioned history does not adequately accommodate the medley of re-assembled subjects who manifest the limbo imagination leaves us, in our interrogation, with our own phantom limb. It also helps answer the question of how we can get at a poetics of feeling history that breaks open the potential for recognizing the voids in the archive. Since this project is my own attempt at intervention, this phantom limb, this embodied feeling of lack, brings me to my central argument, which frames empathy as a way of feeling history that generates the possibility and potential of a more ethical way of being. However, since history as a 
discipline is symptomatic of this lack, in order to gesture towards the poetics of feeling history, it is necessary to engage the kinds of creative interventions that remind us of our shared phantom limb in the first place.

Elizabeth Freeman’s “Turn the Beat Around: Sadomasochism, Temporality, History," is another richly layered suggestion of the ways in which we can gesture towards feeling the trauma of enslavement, despite our distance from such experiences. Freeman writes,

$\mathrm{S} / \mathrm{M}$ might be a way of feeling historical that exposes the limits of bourgeois-sentimental emotional reactions to historical events. Yet it also refuses to eschew feelings altogether as a mode of knowledge. In other words, $\mathrm{S} / \mathrm{M}$, as affect corporealized, rings some changes on what it might mean to theorize historical consciousness - a slippery concept, but one that [she takes] to mean both a latitudinal understanding of individual experience as part of a contingent set of institutional structures... and a longitudinal way of connecting that experience to those in a collective past or future, albeit in a relationship other than simple cause and effect (40). While S/M does not become a central analytical trope in my project, it becomes useful as a way to situate the importance of feeling history, and empathy, by way of a physical imagining. Additionally, Freeman's articulation of S/M is a site from which to gain a more nuanced perspective on the "terror and pleasure" marked by Venus's presence in the archive (Hartman, 1). 


\section{Part II. Bearing Witness and Being-With: Deconstructing Empathy}

Before delving into Beloved and Brief Wondrous Life, however, we must further articulate some of the language and theoretical underpinnings that make it possible to communicate the value and role of empathy in the potential for more ethical modes of being-in-the-world and relating to each other. The problem with presenting empathy as an avenue with which to approach a poetics of feeling history, emerges from the tacit implication that in order to empathize, one must be able to occupy, and metaphysically and transparently know, the body and consciousness of another. Because deconstruction's aim works to highlight and do away with the binary and metaphysical ideology that tries to "ground" discourse, it is also the precise lens through which we might undo this notion of empathy. In fact, as James Clifford points out, "Feeling historical can be like a rug pulled out: a gestalt change perhaps, or a sense of sudden relocation, of being seen from some previously hidden perspective" (420). It is this characteristic of feeling historical the "gestalt change" that allows us to see and be seen "from some previously hidden perspective" - which helps reframe empathy as itself ethical.

The theoretical models of Jacques Derrida and Jean-luc Nancy offer useful tools with which to situate empathy as an avenue toward the poetics of feeling history insofar as these models help highlight the relationship between empathy and history by establishing the conditions of how our being-in-the-world is necessarily mediated by others' being-in-the-world. Nancy's assertion that any discourse relating to the "nature, essence, or end of 'man' must be undone," not only echoes Glissant's call for the decentering of Western man, but also begins to do the work of dismantling by presenting an alternate, and arguably - more ethical - notion of what it means to "be" (Being 
Singular Plural xi). For Nancy, being is necessarily dependent on the other. Nancy writes,

There is no other meaning than the meaning of circulation. But this circulation goes in all directions at once, in all the directions of all the space-times (les espace-temps) opened by presence to presence: all things, all beings, all entities, everything past and future, alive, dead, inanimate, stones, plants, nails, gods - and "humans," - that is, those who expose sharing and circulation as such by saying "we," by saying we to themselves in all possible senses of that expression, and by saying we for the totality of all being. (3)

In other words, for Nancy, to be is to mean, and in order to mean, meaning has to be made between beings. Without this "between" movement, neither being nor meaning could be. In short, "Existence is with: otherwise nothing exists" (4). Moreover, being, as Nancy understands it, is both singular and plural:

Circulation - or eternity - goes in all directions, but it moves only insofar as it goes from one point to another; spacing is its absolute condition. From place to place, and from moment to moment, without any progression or linear path, bit by bit and case by case, essentially accidental, it is singular and plural in its very principle. It does not have a final fulfillment any more than it has a point of origin. It is the originary plurality of origins and the creation of the world in each singularity, creation continued in the discontinuity of its discrete occurrences. (5) 
In The Fragmentary Demand, Ian James further illuminates Nancy's notion of "beingwith":

Nancy's use of the term "being-with" seeks to think our worldly existence with others in a more fundamental or originary manner. Here the 'beingthere' of being-in-the-world can occur only on the basis of a relation with death which is (always) already shared, such that the being if the world itself is given or opened up as a primary being-with, which only subsequently allows for individuation or the singularizing of being-there.

If we can understand our existence in the way that Nancy articulates it above, then it becomes possible to understand how vital empathy is in the context of a more ethical being-with, insofar as empathy as an affect is dependent upon sharing. According to the British and World English Oxford Dictionary, empathy is "the ability to understand and share the feelings of another." The word's etymology is cited as coming from the "early $20^{\text {th }}$ century: Greek empatheia (from em- 'in' + pathos 'feeling') translating German

\section{Einfühlung."}

A deconstructive approach to this definition allows us to formulate empathy as a feeling that emanates both inwardly and outwardly: a "being-in-feeling" with and on behalf of an-other. If I can share a feeling, I require a subject with whom to share feeling. The dialectical movement of empathy is then necessarily imagined on individual terms, but also on the terms of the other. Empathy, in its most ethical sense, requires the cognition of another's irrefutable difference from oneself. In order to empathize, an individual requires a certain kind of awareness about his or her own feelings regarding an 
experience or event, and also the ways in which an-other might feel the experience or event, thus facilitating an ethical relationship. While some deconstructive scholars might argue that empathy requires identification, in fact, empathy cannot simply be a form of identification inasmuch as identification, as it is traditionally understood, emerges from representational language that perpetuates the essentialist notion that individuals are able to "know" another's experience of being-in-the-world. Therefore, a deconstructed empathy does not necessarily require this kind of metaphysical "knowing" and identification. In contrast, identification could function as a subject's recognition of the "certainty" (however nebulous) that s/he can never fully capture, fully comprehend, or inhabit another's understanding of their being-in-the-world by virtue of its impossibility. Imbricated within the understanding that we can never arrive at another being's experience, is Derrida's formulation of bearing witness, which is pertinent to my project insofar as it foregrounds the ethical terms of communicating an experience or event. For us, then, Derrida's bearing witness is the analytical concept that guides our approach to creative interventions like Beloved and The Brief Wondrous Life of Oscar Wao. In a chapter from Sovereignties in Question entitled "Poetics and Politics of Witnessing, Derrida writes, "all responsible witnessing engages a poetic experience of language" (66). It is important to note, that for Derrida, the act of responsibly bearing witness to something, or of offering testimony in regard to something, cannot involve a guarantee of certainty. Indeed,

...as soon as it is guaranteed, certain as a theoretical proof, a testimony can no longer be guaranteed as testimony. For it to be guaranteed as 
testimony, it cannot, it must not, be absolutely certain, absolutely sure and certain in the order of knowing as such. (68)

The reason that testimony cannot be presented as certain is because bearing witness is mediated by a subject's consciousness (and hence language), which is always-already mediated by the biases that emerge from said subject's linguistic engagement. That is, since subjectivity "involves a profound entangling of being, language, and world," then there is no way to guarantee that that which I am bearing witness to, (but am not - in actuality - bearing witness to at that particular moment) is what actually happened (Luszczynska, 69). Instead, responsible bearing witness is predicated upon an act of faith in which

I affirm (rightly or wrongly, but in all good faith, sincerely) that that was or is present to me, in space and time (thus, sense perceptible), and although you do not have access to it, not the same access, you, my addressees, you have to believe me, because I engage myself to tell you the truth, I am already engaged in it, I tell you that I am telling you the truth. Believe me. You have to believe me. (Derrida, 76)

By way of the constitutive element of faith, Derrida's conceptualization of bearing witness has to do with being-with inasmuch as there is an exchange between the subject who bears witness and the subject to whom it is being told. In order to bear witness, then, one necessarily has to be-with. To be is necessarily to bear witness. We cannot not bear witness. We must bear witness. Also significant to our project is that "bearing witness is not through and through and necessarily discursive. It is sometimes silent. It has to engage something of the body, which has no right to speak" (77). It would not be a 
tremendous interpretive leap to read this "body, which has no right to speak" in two ways. First, we can frame the act of bearing witness, as something that happens through "the body, which has (had) no right to speak." In this sense, bearing witness can be understood in the context of enslaved bodies, which were not deemed to have the right to speak. Second, we can also read "the body, which has no right to speak" as the body which finds itself paralyzed to bear witness to the trauma of enslavement because of that body's perceived distance (both temporally and physically) from the lived experiences of the enslaved.

The theoretical intersections of deconstruction, historiography, and postcolonialism, and the potential of affective empathy that can emerge therein, are best examined through the lens of creative interventions that self-reflexively trouble the inherent problems in Western epistemology and which have become textual performances of alternate ways of being and knowing. If literature and imagination can be said to require empathy from readers, then their intersection serves as a site where we can find a glimmer of hope for more ethical, just, and "connected" ways of being. This kind of relationship making would mean that we understand what Nancy calls the "autistic multiplicity" of being (xiii). Although my notion of empathy is not the same as Nancy's compassion, his articulation of compassion as a necessary aspect of being-with that is not "a pity that feels sorry for itself and feeds on itself" and is instead "the contagion, the contact of being with one another in this turmoil" gestures towards the kind of affective empathy that I posit holds the potential for more ethical being-withness (Being Singular Plural xii). If we can understand empathy in this sense, then there is something valuable about recursively, self-consciously trying to imagine what an-other 
experiences. Empathy, then, can be understood as a vehicle for facilitating a selfconscious, worked at, and worked through being-with.

Toni Morrison's Beloved, originally published in 1987, is one example of such a text. Winner of both the Pulitzer and Noble Prizes, and named "The Single Best Work of American Fiction Published in the Last 25 Years" by the New York Times Book Review's Fiction Survey, Beloved has transcended the realm of African American literature and become part of a more collective American literary and cultural psyche. Because of its canonical presence, it might be argued that the novel's hierarchical relationship to other examples of African American or US Latino Literature, works against the ethical imperatives of deconstruction and the empathetic potential therein. However, I would posit that Beloved's presence within a Western literary canon that is becoming less and less homogenized, is precisely what makes it a creative intervention that has clearly affected cultural sensibilities in significant ways, and that helps us get at a poetics of feeling historical by way of empathy.

Junot Díaz's The Brief Wondrous Life of Oscar Wao was published in 2007 to great critical acclaim, following the author's celebrated collection of short fiction, Drown which appeared nearly 10 years prior. Like Morrison, a Pulitzer Prize and other stamps of approval from prominent literary critics, including Michiko Kakutani of The New York Times, have cemented Díaz's reputation, and as such, The Brief Wondrous Life does weighty cultural work. In fact, as a tangible literary manifestation of the kind of linguistic hybridity championed by post-structural and post-colonial theorists, Brief Wondrous Life can also be said to function on behalf of a resistive discourse that problematizes, and interrogates the externally-imposed rigidities of normalizing and oppressive structures of 
power. Like Beloved, the novel's acclaim, which privileges it in the Western literary canon, might be said to undermine its redemptive potential, insofar as it bolsters the role of literary hierarchies. However, if we situate the novel's role in a historically, socioculturally mediated literary tradition, I would suggest that Junot Díaz's preface to his Pulitzer Prize winning novel, The Brief Wondrous Life of Oscar Wao, is another potent and necessary example of the kind of creative intervention that works to responsibly and effectively negotiate the space between recuperative story-telling, and a reconfiguration of the meaning of history on a lived experience. In so doing, I aim to locate the sites from which a more empathetic being-in-the-world might begin to emerge.

\section{Part III. Empathy, Absence, and Identification in Toni Morrison's Beloved}

Creative interventions that engage the historiographical event of enslavement become sites from which we can imagine suffering. This is significant insofar as the act of imagining an-other suffer emerges from empathy, and can lead us toward consolation. It is important to keep in mind that imagination is key here precisely because it is the affective imaginative rupture that forces us - as readers, writers, and communicators - to use a linguistic ordering that is outside of representational language. This rupture can only function on the condition that "meaning" is being "made" via poetic language. Poetic language, setting, tone, form, style, etc. (pathos) generate the imaginative rupture that gives way to empathy. An ethical and deconstructive construction of empathy gestures towards the notion that meaning is contextually oriented and "being" is a necessarily singular plural event. 
It is important to note that the role of affective empathy and its ethical implications in Beloved has been attended to by several critics, but Molly Abel Travis's "Beyond Empathy: Narrative Distancing and Ethics in Toni Morrison's Beloved and J.M. Coetzee's Disgrace," is well-aligned with my argument. Travis writes,

Most conventional arguments for the redemptive power and ethical function of narrative literature point to literature's ability to cultivate humanity through the creation of an empathy that can serve as the foundation for a multicultural ethics. This empathy, so the argument goes, is created through the reader's identification with the narrator and/or characters in a process that allows us to transcend differences. However, in considering the possibilities of narrative empathy, one finds no guaranteed relationship between empathy and a socialized ethical response. (232)

I would like to point out, here, that Travis, as I do, counters the understanding of empathy's ethical potential by way of the identification between a reader and a literary character. As I have argued, however, the kind of empathy this project imagines, does not find its roots in identification, but in the recognition of the limits and impossibility of identification. Moreover, because Travis finds no "guaranteed relationship between empathy and a socialized response," she dismisses the ethical potential of affective empathy and argues instead,

that the most ethical act for literature is not the bridging of gaps through the creation of empathy, but the articulation and keeping alive of intractable ethical questions about the asymmetrical relationship between 
self and other...It is only through openness to alterity that there can be an ethical relation. Without a relation to that which interrupts our epistemological projects to contain the other, there would be no ethics. (232).

I agree with Travis's claim that literature's "most ethical act" is its ability to articulate and sustain the mode of questioning that interrogates and intervenes upon "epistemological projects" that "contain the other," but I would add that the specific epistemological project, here, is history itself. Furthermore, while I also agree that empathy's ethical role is not predicated upon the "bridging of gaps," I would disagree that it has no ethical potential whatsoever, precisely because the kind of questioning that Travis suggests necessitates empathy. In other words, to be open to alterity and to sustain the "ethical questions" that allow us to intervene upon history requires a capacity to empathize. Aside from bolstering Hartman, Holland, and Glissant's negotiations of the problem of history by an ethics of questioning, an ethical interrogation of history - as Travis has delineated - I argue, is necessarily motivated by the kind of empathy that does not emerge from identification. Rather, this empathetic relationality is based upon the recognition that identification cannot occur in any true or transparent way. Therefore, the kind of empathy that reading Beloved affords, is one that recognizes the limits of our inhabited physical body, and that requires us to do the difficult work of imagining the psychical and physical experience of enslavement, despite knowing that we can never fully arrive at that experience. In this way, Beloved is a powerful example of how poetic language allows us to ethically bear witness to a particular historiographical event. 
One of the facets that makes Toni Morrison's Beloved such a rich example of literature's affective potential is the way in which the novel performs language's inability to capture, write, and (re)present that which refuses meaning; that which Julia Kristeva would call "the abject": ${ }^{2}$

one of those violent, dark revolts of being, directed against a threat that seems to emanate from an exorbitant outside or inside, ejected beyond the scope of the possible, the tolerable, the thinkable. It lies there, quite close, but it cannot be assimilated (Powers of Horror 2).

Beloved is in many ways, Morrison's intervention upon the archives of history. As Marilyn Sanders Mobley notes in “Memory, History and Meaning in Toni Morrison's Beloved," the "actual story upon which the novel is based in an 1855 newspaper account of a runaway slave from Kentucky named Margaret Garner," who kills her child when she learns she will be forced back into captivity as a result of the Fugitive Slave Law. (193). By way of the novel, Morrison reconfigures Garner's archival presence into that of Sethe, whose murdered child haunts 124 - the house where Sethe resided with her daughter Denver, and her mother-in-law, Baby Suggs. Sethe's sons, Buglar and Howard, "had run away by the time they were thirteen years old" because of Beloved's enraged haunting of the house (Morrison, 3).

\footnotetext{
2 Julia Kristeva's work is not a central lens of analysis in this project, but her articulation of abjection captures the difficulties of linguistically rendering the trauma of enslavement.
} 
Much of the critical work engaging Morrison's novel recognizes and explores the intersections of history and narrative, ${ }^{3}$ which Beloved so centrally foregrounds. As Christopher Peterson notes in "Beloved's Claim," the novel, insofar as it engages a specific event in the historiography of the enslaved, "imagines a triumph over the Fugitive Slave $\mathrm{Law}^{4}$ that should caution readers against the almost unanimous characterization of Beloved as a novel of historical recovery rather than of historical invention" (553). For Peterson, Morrison's negotiation of the material dimensions of enslavement with an imagined "alternate past," is what allows the novel to be read as an ethical approach to the relationships between self and other.

Also important is that Beloved not only thematizes the ethical implications of linguistic representation of the horrors of institutionalized enslavement, but its form does as well. This point becomes especially evident in last section of the Sethe, Denver, Beloved trifecta where it seems that Beloved - not quite a ghost, and not quite a living person, not quite a woman, and not quite a child - speaks. By way of Morrison's brilliant talent, this entire section works to ethically write the unspeakable conditions of the Atlantic Slave Trade and its aftermath, while simultaneously underscoring the ways in which empathy is necessarily constitutive of being-with. Morrison writes,

I am Beloved and she is mine...how can I say things that are pictures I am not separate from her there is no place where I stop her face is

\footnotetext{
${ }^{3}$ Hortense Spillers's “Mama's Baby, Papa's Maybe," a frequently cited critical piece on Beloved, considers the intersection of history and narrative, and analyzes how the economy of enslavement commodified maternal bodies and their relationship to their offspring.

${ }^{4}$ Refer to Stephen Best and Saidiya Hartman's "Fugitive Justice," for a critical piece that addresses the material and legal conditions of enslavement and of calls for redress made by ex-slaves in abolitionist America.
} 
my own and I want to be there in the place where her face is and to be looking at it too a hot thing (248).

The question posed about being able to say things which only convey meaning as images speaks to the way that the experiences of the enslaved were mediated (throughout the horrific journey from Africa to the New World and for long afterward) by a lack of communication between enslaved subjects and those who colonized them. Significantly, it is precisely by way of the colonizer(s) that enslaved subjects enter a public discourse in the first place. The fragmentary nature of Beloved's section, conveyed by the extra distance between words on the page, makes the section even more complex. The spaces between phrases make it seem as though many people are speaking and experiencing this portion of the novel. The experiences and images are not Beloved's alone, but those of the Africans that came before, and will continue to come, in the holds of ships.

This section is also punctuated with the phrase "a hot thing." This "hot thing the men without skin push them through with poles" stands in for the scalding iron used to brand slaves (248). The fact that it ruptures through the fragmented narrative several times further supports my suggestion that this section in the novel attempts to capture a very specific, yet universal (inasmuch as it was experienced by millions of enslaved persons, and inasmuch as we can imagine the pain of being branded $)^{5}$, account of suffering during the Atlantic Slave Trade. The repetition of the phrase also simulates the movement of a branding iron - moving forward to brand a body, then retracting, then moving forward again to brand another.

\footnotetext{
${ }^{5}$ Elizabeth Freeman's "Turn the Beat Around: Sadomasochism, Temporality, History" examines the way in which using a tool, such as a whip, might help further the way in which we can feel historical via S/M.
} 
Also interesting is the way in which the white men are described. That they are described as "men without skin" seems to invert the hierarchically ordered understanding of "whiteness" as superior to blackness inasmuch as for Beloved, the white men are lacking; they are without skin (249). The affective work of this phrase is powerful. It dexterously reconfigures an entire literary (and socio-cultural) history's understanding of skin color, and how/what it signifies. It brings to the forefront the strangeness of white skin in the eyes of someone who has never known whiteness as any kind of norm, and it also works to convey the inanity of placing value on a person by way of their skin color. That our skin color can determine some kind of material or economic worth, in this example, seems so ludicrous, so asinine, that it brings into question the entire validity of historical narratives of enslavement that make meaning based on binary oppositions. In this sense, this phrase is in itself a fascinating example of the ways in which fiction can intervene on dominant discourses, and literally turn the oppressive ideologies that lie therein on their heads.

Another aspect of this section that demands consideration in light of its unique form is when Morrison writes,

$$
\begin{aligned}
& \text { All of it is now it is always now there will never be a time when I am } \\
& \text { not crouching and watching others who are crouching too I am always } \\
& \text { crouching. (248) }
\end{aligned}
$$

This moment in the section can be said to speak to the spatial-temporality of enslavement and to the fact that its institutionalization has left deep fissures in our current sociocultural moment in time. Morrison articulates a black cultural sensibility, which symbolizes the systemic violence of enslavement, but also the systemic racism that limits 
and encroaches upon the freedom of black communities today. We can see direct evidence of the vestiges of slavery and its attendant racism as they are made manifest in very particular spaces in cities across the US.

Additionally, Morrison's writing and rewriting of "I am always crouching" reminds us of our shared phantom limb and the limbo imagination of enslaved subjects articulated by Wilson Harris:

Limbo then reflects a certain kind of gateway to or threshold of a new world and the dislocation of a chain of mile. It is - in some ways - the archetypal seachange stemming from Old Worlds and it is legitimate, I feel, to pun on limbo as a kind of shared phantom limb (4).

The notion of limbo as a dance that requires a backwards crouching that is ever forcing us closer to the ground by limiting the literal space within which to negotiate our bodies is not only reminiscent of the physical lack of space that the enslaved were subjected to in the holds of ships, but also to the social constrictions that were - and are - imposed on African American peoples by a system of oppression that maintains binary oppositions by way of representational language. The connotations of limbo as a space that is inbetween, that is neither here nor there, are also indicative of a very particular way of experiencing and understanding being-in-the-world, which cannot be easily assimilated by representational language. As such, it can be argued that it is precisely this limbo imagination that affords a space from which ethical creative interventions can emerge. The metaphor of a limbo pole being lowered towards the ground that forces a physical body to maneuver and negotiate the space left to it, becomes an extremely poignant one 
in relation to the kinds of texts that materialize out of a consciousness that is mediated by oppressive structures of power.

The entire section where Beloved speaks is marked by a sense of disorientation and a cyclical, infinite temporality. This kind of non-linear temporal conception speaks to the imbricated, repetitious, and ultimately non-metaphysical understanding of past experiences. It speaks to the palimpsest of being and to the way that historical events are not relegated to the past, but always-already occurring and affecting, and gesturing towards a future. Morrison's dazzling constructions of phrases and images manage to situate Beloved, and those she represents, in all places at all times. This is particularly evident if we look at moments in the text that are constructed in a way that gestures towards something without arrival. If we understand desire as perpetual non-arrival, then it follows to say that the entire section is wholly focused on a consistent, all-consuming desire for presence, recognition, and autonomy. For example, when Morrison writes, "when he dies on my face I can see hers she is going to smile at me she is going to her sharp earrings are gone," Beloved demonstrates an urge to be recognized by way of "her" (Sethe's) smile (250). Sethe's smile, as it would be both for and toward Beloved, can manifest only by way of recognition. ${ }^{6}$

Arguably, this longing to be smiled at speaks to a significant particularity of the human condition insofar as the urge to be recognized is, ultimately, the urge towards understanding one's own being or existence as it relies on being acknowledged by the other (Hegel, 631). The smile that Beloved so desires is dependent upon the empathetic

\footnotetext{
${ }^{6}$ In "The Bonds of Love and the Boundaries of Self in Toni Morrison's Beloved," Barbara A. Schapiro takes a psychoanalytical approach to the notion of how being is necessarily mediated by an-other.
} 
relationality of being. The phrase is repeated though, "she is going to smile at me she is going to" and then after a break, "her sharp earrings are gone." The repetition not only builds the anticipation of being recognized, but since it is constructed in the present continuous tense, as an event that is presently on the verge of occurring, and will continue to recur in the future but does not come to be, ("her sharp earrings are gone") becomes a literal textual performance of the "violent relatedness" of being (Morrison, $250, B S P$, xii). The phrase repeats throughout the entire section of the novel and Morrison's use of tense and repetition, and the way that usage generates a feeling of continual anticipation also echoes the anticipation that emerges from the temporal space that arises immediately after slavery was abolished - especially as it encapsulates a moment in time that anticipates a more just and hopeful future that cannot manifest as long as the residual hierarchical understandings of race still operate within a particular dominant discourse.

The linguistic play that Morrison engages imbues the segment with the singular plurality of being. When Beloved says that she "want[s] the join" - which implies that there is a distance to bridge - it seems as though she is speaking for all of the enslaved whose rights to peace and belongingness were viscerally and violently ignored by those who perpetuated the commodification of bodies and suffering during the trans-Atlantic Slave Trade (252). As the section closes, Morrison writes,

Sethe sees me see her and I see the smile her smiling face is the place for me it is the face I lost she is my face smiling at me doing it at last a hot thing now we can join a hot thing (252). 
This "wanting to join," demands close attention if we consider it as exemplary of "being" in the non-representational sense. That is, in this section, the desire to join can be understood as the desire to recognize one's selfhood as constitutive of the other. Beloved cannot be - or at least, feel like she is - without joining Sethe. That Sethe is the maternal body that brings Beloved to physical being is not to be ignored, and while it highlights our very literal requirement of an-other in order "be," Beloved's desire to join, to come together with Sethe, seems to most poignantly articulate the radical opportunity for empathetic relationality that alternate ways of knowing can afford us. And even within the textual representations of the non-representational, when Sethe smiles at Beloved at last, when she and Beloved are allowed the merge, the violent relatedness of being is still being punctuated by the hot thing; the literal and figurative marker of enslaved bodies, of their worth, and of their status within an oppressive, radically not-with (thus radically unethical), structure of power.

This sense of a separate-togetherness lends itself well to a reading of Beloved's section as a kind of pre-discursive, extra-linguistic temporality. I would suggest that this section also signifies the moments of Beloved's conception, her birth, her death, her phase as a disembodied ghost, and her rebirth as an embodied one. Morrison writes, my face is coming I have to have it I am looking for the join I am loving my face so much my dark face is close to me I want to join she whispers to me she whispers I reach for her chewing and swallowing she touches me she knows I want to join she chews and swallows me I am gone now I am her face my own face has left me....I want to be the two of us. (252) 
I would suggest that these fragments coalesce to represent the laborious process of birthing a child. It is as though Beloved is putting words to the challenge of being born, of coming to be in the world as a physical body with no choice but to exist. The phrases work to articulate the movement of straining towards. Like the trauma of being constricted by bodies and the hull of a ship during the transportation of the enslaved, only to arrive in a New World, which requires an entire reconfiguration of "being-in-theworld," the trauma of being born is also mediated by a constricted passage. Coming into the world all screams, placenta, and helplessness, becomes an apt metaphor for the condition of enslaved subjects emerging from the holds of ships covered in filth, tears, and without a foothold in the New World.

This reading becomes possible insofar as the temporality in this portion of the novel is not only non-linear, but always already. Since this section can be said to function outside any and all conceptualizations of "time," as such, we can understand "temporality" here as an all-encompassing sub-consciousness. This trajectory is significant to follow because it affords a reading of Beloved as representative of something so outside of "reason," that it cannot be understood or mediated by way of language (read: logic and linearity) at all. Although this extra-discursive condition is expressed textually via language - because language is, after all, constitutive of "meaning," however inadequate the ability to signify may be - the section's form makes meaning by way of pictures. These flashes of experience are meaning-full because they do not bear witness to the trauma of enslavement as what it is (that which refuses to be signified) but as what it feels like. The abjection of being transported in the filth and misery of a slave ship's hold makes signification impossible, but by presenting flashes of 
that abjection, there is a sense of understanding - a trace - of what the transportation of the enslaved did to bodies.

For example, Morrison does not write, "some of the enslaved ate their own fecal matter for sustenance." This kind of writing connotes a record of observation, of telling what "really happened" by way of gathering data, and representing it to readers as a kind of final signifier. Instead, Morrison writes "some who eat nasty themselves" (248). This phrasing eludes immediate understanding and brings to light the almost inconceivable conditions of despair in the holds of slave ships. By way of this section though, we are forced to conceive it. Despite the seemingly endless space between "us" and "them," between "then" and "now," we are forced to imagine the scene, and by way of imagining it, we - in some sense - feel it. And however inadequate or inaccurate this imagining may be, it brings us closer to understanding that we are responsible for and deserving of a collective consolation by simple virtue of the fact that without the event of enslavement, we would not hold this text in our hands. It is by way of being exposed to language that does not try to fix meaning and instead works to perform the slippery nature of signification, that readers can begin to re-understand the way experiences are singularly nuanced, yet able to be felt - in some way - as a collective condition of being. This reunderstanding of relationality and being surfaces from the empathetic affect which novels that challenge Western epistemology can generate and demands that we sustain the ethics of interrogating history. 


\section{Part IV. Empathy, Mediation, and Bearing Witness in The Brief Wondrous Life of Oscar Wao}

Like Beloved, Brief Wondrous Life is a novel brimming with the potential of deconstructive ethics insofar as it also works to cultivate affective empathy. Differently, from Beloved, however, Brief Wondrous Life employs language that is more indicative of an more urban community, which is itself constituted by difference (both cultural and linguistic), and by the diverse influences of immigrants and "minority" populations. ${ }^{7}$ One of the more significant questions that emerge from the analytical intersections of deconstructive ethics, history, and empathy is the way in which Díaz's novel speaks to the problems of ethically bearing witness to history. In The Ethics of Community, Ana Luszczynska reminds us of Derrida's notion of bearing witness:

Derrida claims that all responsible witnessing must involve a poetic experience of language. When I bear witness to you, a vow or an oath is always implied: you have to believe me. The "to you" of any communication or relation must simultaneously be a promise. All relation is based upon this extra-discursive event that happens within language as a pledge...Rather than a simultaneous or coexistent being and being-with, Derrida maintains that I am and can only be after having been in a way of responsibility to the other (69).

The idea that being is mediated by our responsibility to the other means that being necessarily requires an empathetic (and thus ethical) relationality, which might manifest

\footnotetext{
7 Ramon Saldivar's "Historical Fantasy, Speculative Realism, and Postrace Aesthetics in Contemporary American Fiction," argues for a different literary term ("historical fantasy") to accommodate Brief Wondrous Life's stylistic medley and the way in which it manifests a new kind of historiography.
} 
by way of reading historiographical novels. Brief Wondrous Life allows us closer proximity to the ethics of bearing witness by way of the novel's narrator, the novel's form, and the various stylistic elements that tell Oscar's (and our) story.

Díaz's novel traces the historically mediated trajectory of Oscar Wao, a young, Dominica, science fiction ${ }^{8}$ fanatic who by sophomore year "found himself weighing in at a whopping 245 (260 when he was depressed, which was often)" (19). Oscar had always been a "young nerd," a "social introvert who trembled with fear during gym class," and "who was always hiding out in the library" $(20,21,22)$. In fact, Oscar "couldn't have passed for Normal if he'd wanted to" (21). Oscar's naïve and overly romanticized approach to falling in love, what Díaz writes as "the gravitational mass of love, fear, longing, desire, and lust that he directed toward any girl in the vicinity...broke his heart every day" (23). As the son of Belicia Cabral, once a nexus of sheer will and a "cuerpazo so berserk that only a pornographer or a comic-book artist could have designed it with a clear conscience," and later physically and psychologically diminished by years of single motherhood, a life of hard work in diaspora, and ravaged by cancer, Oscar's romantic naïveté begins to make some sense (Díaz, 92). Díaz tracks the trajectory of Beli’s life in the DR beginning with her father, Abelard, and the demise he met at the hands of Trujillo, and ending with the consequences of Beli's tendency to fall utterly and completely in love with men who had little respect for her.

We are given the story of The Brief Wondrous Life of Oscar Wao by way of Yunior, the novel's "sole narrator," who "establishes a link between storytelling and

8 T.S. Miller's "Preternatural Narration and the Lens of Genre Fiction in Junot Díaz The Brief Wondrous Life of Oscar Wao" and Daniel Bautista's "Comic Book Realism: Form and Genre in Junot Díaz's The Brief Wondrous Life of Oscar Wao" are useful critical pieces which engage the novel's engagement with science fiction more closely. 
dictatorship" (Machado-Saez, 527). In "Dictating Desire, Dictating Diaspora: Junot Díaz's The Brief Wondrous Life of Oscar Wao as Foundational Romance," Elena Machado Saez notes that "by pulling back the veil of an omniscient voice and revealing Yunior as the narrator, Díaz underscores the dangers involved in accepting the authenticity of any historical narrative, even the fiction that he himself writes" (527). This point is pertinent to our analysis insofar as it frames the novel as the kind of historiographical work that manifests the kind of empathetic, and thus ethical trajectory of questioning and interrogation that serves to intervene upon the archives of history. Furthermore, Díaz says that Brief Wondrous Life is "not only a text... - it's also a game. As a reader you have to put the book together in your head, but you could only do that by answering some important questions for yourself: why is Yunior telling THIS story?" (“The Yale Literary Magazine Interviews Junot Díaz," 27). By presenting the novel as a game, as the kind of text that necessitates an interactive reading that is mediated by questions, Díaz presents it as a text that demands the deconstructive ethics and the empathy we are trying to inaugurate by way of this project.

In “'Reassembling the Fragments': Battling Historiographies, Caribbean Discourse, and Nerd Genres in Junot Díaz's The Brief Wondrous Life of Oscar Wao," Monica Hanna argues

that the novel strives for a "resistance history" which acts as an alternative to traditional histories of the Dominican Republic by invoking a multiplicity of narrative modes and genres. By incorporating genres like magical realism and "nerd" genres that include comics and science fiction, Díaz develops a historiography that shifts the narrative structure as well as 
the subject of history, allowing for a representation of national history that is cognizant of its various, sometimes dissonant, elements. Yunior seeks to present Dominican history in this way in order to resist the conformity and univocality insisted upon by the national power structure best personified by the figure of the Dominican dictator Rafael Trujillo. (500)

Hanna's analysis of the novel is very much aligned with the theoretical and ethical perspectives that were delineated in the introduction, especially if we consider her point that the novel is - in some way - "cognizant" of history's "various, sometimes dissonant, elements." Hanna also argues, "Yunior struggles with the silences that pervade both the history of Oscar de Léon's family and that of the Dominican Republic," and the way he negotiates these silences is to adopt "several narrative frames" that examine the "story from multiple perspectives" (500). For Hanna, and for us,

it is this very multiplicity that becomes the cornerstone of Yunior's narrative and historiographic stance, allowing him to document and reconstruct a history that is otherwise unrecoverable because of its official nullification. (500)

Echoing the problem of histories and historiography foregrounded in our introduction, Hanna rearticulates these issues and how they manifest in The Brief Wondrous Life of Oscar Wao. 
In order to expand upon the historiographical negotiations of the novel, it is useful to consider Yunior's preface to the novel, where the motifs of fukú and zafa are introduced and contextualized for readers: ${ }^{9}$

They say it came first from Africa, carried in the screams of the enslaved; that it was the death bane of the Tainos, uttered just as one world perished and another began; that it was a demon drawn into Creation through the nightmare door that was cracked open in the Antilles. Fukú americanus, or more colloquially, fukú - generally a curse or doom of some kind; specifically the Curse and the Doom of the New World (Díaz 1).

Fukú, then, can be understood as the curse of disenfranchisement that colonial imperatives have made manifest in Caribbean (and various other) spaces. For Díaz, fukú functions as the residue of the violations inherent in colonial initiatives, and its power can be wielded by both individuals and institutions. This articulation of fukú can be said to encapsulate the terror, violence, fragmentation, and violence of enslavement and its aftermath. Zafa, on the other hand, becomes a counterspell to the doom of fukú. By functioning as a kind of blessing that keeps ill wishes at bay, zafa is a powerful tool that can be used "in the hope that the bad luck will not have had time to cohere" (Díaz 7). These "superstitions," as non-Western understandings of fate, luck, and destiny, are representative of the alternate ways of understanding the world that Díaz engages throughout the novel, and remind us the potency behind a rearticulation of myth as guiding tropes in historiographical projects.

\footnotetext{
${ }^{9}$ Find another reading of fukú as part of Diaz's "decolonial theory," in Jose David Saldivar's "Conjectures on 'Americanity' and Junot Diaz's 'Fukú Americanus' in The Brief Wondrous Life of Oscar Wao"
} 
Beli's "lost years" can function as another apt example of language's slippery

nature. Before coming to live with La Inca "[Beli] had lived with another foster family, monstrous people if the rumors are to be believed, a dark period in her life neither she nor her madre ever referenced. Their very own pagína en blanco" (Díaz 78). ${ }^{10}$ If we follow this vein, then we see how Beli's condition of being-in-the-world is always mediated by an urge to escape and by the years she lost. Díaz writes,

If I had to put it into words, I'd say what she wanted, more than anything, was what she always wanted throughout her Lost Childhood: to escape. From what was easy to enumerate: the bakery, her school, dull-ass Bani, sharing a bed with her madre, the inability to buy the dresses she wanted, having to wait until fifteen to straighten her hair, the impossible expectations of La Inca, the fact that her long-gone parents had died when she was one, the whispers that Trujillo had done it, those first years of her life when she'd been an orphan, the horrible scars from that time, her own despised black skin. (80, emphasis mine)

Beyond providing an example of Díaz's (and Yunior's) recognition of the problem of putting experiences and feelings into words, this excerpt also demonstrates how language constitutes our being-in-the-world, as well as our relationship to the other and to

\footnotetext{
10 The motif of blank pages is significant throughout the novel. And references to the blank pages seem to manifest in sites where the suffering being described in the novel is almost beyond the realm of even imaginative or poetic signification. However, despite the difficulty of linguistically rendering the violent infliction of pain against another being, I would suggest that the motif of the blank pages gestures towards language's inadequacy. In Specters of the Atlantic, Ian Baucom explores Granville Sharp's account of the massacre aboard the slave ship, Zong. The manuscript's 133 pages and the blank pages/spaces Baucom finds therein, "figures the emergence of the oppositional 'melancholy realism' that dominates the representational logic of almost all the subsequent works which have attempted to offer their testimony to the truth of this event" (133).
} 
ourselves. The excerpt also points to the structures of power from which we are trying to escape. Beli's obligations to La Inca, as a bakery employee and student, as well as the simultaneously self and externally-imposed obligations that compel her to buy particular kinds of dresses, and to want to straighten her hair - yet another way of reinforcing the aesthetic values of the colonizers - and her lack of family, a "normalizing" institution in and of itself - all worked Beli to mold her into a particular kind of person: one whose ambition and potential seem at odds with one another, and whose general sense of wellbeing and peace of mind were precluded by the limitations that language sets forth. The fact that neither La Inca nor Beli spoke about the Lost Years is indicative of the way in which language makes memory seem closer than it does when experienced non-verbally.

Beli and La Inca also seem to recognize that language mediates their being-with and that poetic language, spoken purposefully, in good faith, and with the aim of bringing about a communal goal that necessarily requires the recognition of being-with. An example of this can be found in the novel when Beli disappears after her affair with the Gangster. Of La Inca’s "divine" act of prayer, Díaz writes, "In no time at all the room was filled with the faithful and pulsed with a spirit so dense that it was the rumored that the Devil himself had to avoid the Sur afterward for months" (145). This coming together - even within the realm of what can be said to be the Western, metaphysical discourse of Catholicism (and the numerous implications that lie therein) - is predicated upon a sense of empathy and being-with. That is, in order for these women to come together in prayer, and as Díaz points out, who "suffered shetaat (spiritual burnout)," then they had to be motivated to do so from a mutual sense of being-with, a mutual recognition of their 
shared place within a socio-political structure that works only on behalf of itself and against the needs and well-being of others (145).

In "The Moral Obligations of Living in a Democratic Society" Cornel West speaks towards an active empathy when he writes, "Empathy is not simply a matter of trying to imagine what others are going through, but having the will to muster up the courage to do something about it. In a way empathy is predicated upon hope" (127). West's articulation of empathy demonstrates that it indeed requires something of us. In other words, empathy requires us to do something on behalf of others because inasmuch as we are for others, we are simultaneously "taking care" of ourselves. We feel empathy, we recognize it as an affect or feeling, and in the space of that recognition it motivates us to will it into ethical being. In this sense, empathy is more than a feat of imagination, it is also an action; a way of being that is based on a motivation to engage with others by way of an ethical questioning that allows to feel our proximity or distance from said other. The ways in which we bridge these spatial or temporal separations are necessarily ethical only inasmuch as we recognize the distance between ourselves and an-other, and try to mediate it by way of an ethical interrogation. 


\section{References}

Baucom, Ian. Specters of the Atlantic. Durham: Duke University Press, 2012. Print.

Best, Stephen, and Saidiya Hartman. "Fugitive Justice." Representations 92.1 (2005): 115. JSTOR. Web. 8 Aug. 2012.

Clifford, James. "Feeling Historical." Cultural Anthropology 27.3 (2012): 417-26. Wiley Online Library. Web. 19 Oct. 2012.

Derrida, Jacques. "Poetics and Politics of Witnessing." Sovereignties in Question. Ed. Outi Pasanen and Thomas Dutoit. New York: Fordham University Press, 2005, pp. 65-96. Print.

Díaz, Junot. The Brief Wondrous Life of Oscar Wao. New York: Penguin Books, 2007. Print.

Freeman, Elizabeth. "Turn the Beat Around: Sadomasochism, Temporality, History." differences: A Journal of Feminist Cultural Studies 19.1 (2008): 3270. MLA International Bibliography. Web. 19 Oct. 2012.

Glissant, Edouard. "The Quarrel with History". Caribbean Discourse: Selected Essays. Trans. J. Michael Dash. Charlottesville: UP of Virginia, 1989. 61-92. Print.

Hartman, Saidiya. "Venus in Two Acts". Small Axe. 26 (June 2008): 1-14. Print.

Hegel, Georg W. The Phenomenology of Spirit. Ed. William E. Cain, Laurie A. Finke, Barbara E. Johnson, John M. McGowan, and Jeffrey J. Williams. New York: W.W. Norton \& Company, 2001. 630-36. Print.

Hoffman, Michael L. "Introduction." Empathy and Moral Development: Implications for Caring and Justice. Cambridge, UK: Cambridge UP, 2000, pp. 263-272. Print.

Holland, Sharon Patricia. 'Bakulu Discourse: Bodies Made 'Flesh' in Toni Morrison's Beloved". Raising the Dead. Durham and London: Duke UP, 2000. 41-67. Print.

James, Ian. The Fragmentary Demand: An Introduction to the Philosophy of Jean-luc Nancy. Palo Alto, CA: Stanford University Press, 2006. Print.

Kristeva, Julia. Powers of Horror: An Essay on Abjection. New York: Columbia UP, 1982. Print.

Luszczynska, Ana M. The Ethics of Community. New York: Continuum, 2011. Print.

Morrison, Toni. Beloved. New York: Vintage Books, 1987. Print. 
Nancy, Jean-luc. Being Singular Plural. tr. Robert D. Richardson and Anne E. O'Byrne. Palo Alto, CA: Stanford University Press, 2000. Print.

Nancy, Jean-luc. The Inoperative Community. Minneapolis: University of Minnesota Press, 1991. Print. 